\title{
Clustering of Comb and Propolis Waxes Based on the Distribution of Aliphatic Constituents
}

\author{
Angela R. Custodio ${ }^{a}$, Márcia M. C. Ferreira $^{b}$, Giuseppina Negri $^{c}$ and Antonio Salatino $^{*, d}$ \\ ${ }^{a}$ Universidade São Francisco, Avenida São Francisco de Assis, 218, Jardim São José, CP 163, 12916-900 \\ Bragança Paulista - SP, Brazil \\ ${ }^{b}$ Instituto de Química, Universidade Estadual de Campinas, CP 6154, 13084-971 Campinas - SP, Brazil \\ ${ }^{c}$ Universidade Bandeirante de São Paulo, Rua Maria Cândida, 1813, 02071-013 São Paulo - SP - Brazil \\ ${ }^{d}$ Instituto de Biociências, Universidade de São Paulo, CP 11461, 05422-970 São Paulo - SP, Brazil
}

\begin{abstract}
Os resultados obtidos com a análise química de 41 amostras de ceras de própolis e 9 amostras de ceras de favos de Apis mellifera, coletadas principalmente no Brasil, foram estudados usando Análise de Componentes Principais e Análise Hierárquica de Grupos. Na análise quimiométrica foram consideradas a distribuição de hidrocarbonetos e de resíduos alcoólicos e ácidos de monoésteres. O dendrograma obtido revelou afinidades químicas e diferenças que não puderam ser constatadas com a simples inspeção visual dos dados. Nenhuma diferença consistente foi detectada entre ceras de própolis e de favos. Os resultados deste e de outros trabalhos sugerem que hidrocarbonetos, ácidos carboxílicos, álcoois alifáticos e ésteres das ceras de própolis e de favos são produzidos pelas abelhas e, portanto, as diferenças detectadas entre uma e outra região são mais dependentes de fatores genéticos relacionados aos insetos do que da flora local. As amostras analisadas reuniram-se segundo dois grandes agrupamentos, um deles contendo exclusivamente amostras coletadas no Estado de São Paulo. Os resultados são discutidos levando em consideração o fato de que a africanização das abelhas teve início nesse estado, ocorrendo posteriormente a sua irradiação para outras partes do Brasil.
\end{abstract}

Chemical composition data for 41 samples of propolis waxes and 9 samples of comb waxes of Apis mellifera collected mainly in Brazil were treated using Principal Component Analysis (PCA) and Hierarchical Cluster Analysis (HCA). For chemometrical analysis, the distribution of hydrocarbons and residues of alcohols and carboxylic acids of monoesters were considered. The clustering obtained revealed chemical affinities and differences not previously grasped by simple eye-inspection of the data. No consistent differences were detected between comb and propolis waxes. These and previous results suggest that hydrocarbons, carboxylic acids, aliphatic alcohols and esters from both comb and propolis waxes are bee-produced compounds and, hence, the differences detected between one and another region are dependent on genetic factors related to the insects rather than the local flora. The samples analyzed were split into two main clusters, one of them comprising exclusively material collected in the State of São Paulo. The results are discussed with respect to the africanization of honeybees that first took place in that State and therefrom irradiated to other parts of Brazil.

Keywords: propolis wax, comb wax, hydrocarbons, wax esters, Hierarchic Cluster Analysis

\section{Introduction}

Propolis or "bee glue" is a complex resinous blend of bee and plant derived products that are used by bees in their hives as a general purpose sealer, draught excluder ${ }^{1}$ and antibiotic. Propolis typically consists of inorganic compounds, waxes and other organic substances, such as phenolics and volatiles, the composition ${ }^{2}$ being dependent

\footnotetext{
* e-mail: asalatin@ib.usp.br
}

upon the local flora. It has been shown to possess antiviral, fungicidal, antibacterial, antiulcer, immunostimulating, cytostatic and hypotensive ${ }^{2-7}$ activities.

It is generally assumed that bees collect propolis from buds and wounds of trees. Many plant species have been proposed as sources of propolis components, ${ }^{3}$ but direct evidences from chemical analyses have been provided only in few cases. Poplar buds, especially from Populus nigra, have often been pointed out as sources of propolis ${ }^{2}$ in temperate zones. Of special interest is the origin of 
propolis components in South America, because only rarely poplar trees are cultivated in tropical regions.

A waxy material with composition similar to comb wax can be obtained from propolis by treatment with hot chloroform. In comparison to beeswax (comb wax), much less is known about the composition of propolis waxes. Seifert and Haslinger ${ }^{8,9}$ found, among other classes, alkanes, alkenes, alkadienes, monoesters, diesters, aromatic esters, ketones and fatty acids in propolis waxes. Beeswax is a complex mixture ${ }^{10,11}$ of organic compounds belonging to several chemical classes. Samples of propolis and comb waxes of Apis mellifera from Brazil yielded predominantly monoesters, formed by moieties of carboxylic acids and alcohols with unbranched carbon chains, followed by hydrocarbons with odd numbers of carbon atoms. ${ }^{12-14}$ Triterpenic alcohols, including $\alpha$-amyrin, $\beta$-amyrin, lupeol and its respective acetates were found in five samples of propolis waxes ${ }^{14}$ from the State of São Paulo (Brazil), corresponding to more than $20 \%$ of the wax. Pereira et al. ${ }^{15}$ detected alkanes with 26-35 carbon atoms in crude hexane extracts of Brazilian propolis.

Differences in composition between propolis waxes of Apis mellifera from Brazil and Europe may be due to genetic factors. Among these, it is important to mention the extensive hybridization between the European bees A. mellifera mellifera and A. mellifera ligustrica with the African bee A. mellifera adansonii, which took place soon ${ }^{16}$ after the introduction of the latter in Brazil in the 1950's. Genetic differences between populations of Apis mellifera in Brazil have been established, the reason for which having been attributed to different degrees ${ }^{16-20}$ of hibridization.

Simple eye inspection of the distribution of hydrocarbons and acid and alcohol moieties of esters of propolis and comb waxes from different regions of Brazil enabled neither detection of consistent differences between samples ${ }^{12,13}$ nor grouping of samples, even when pentacyclic triterpenes ${ }^{14}$ were found in propolis waxes. The comparison of complex data sets and their statistical treatment requires computerized means of analysis. Chemometrics, a multivariate method of statistical analysis, has proved to be an effective way to deal with complex chemical data.

The aim of the present work is to treat chemical data of propolis and comb waxes by PCA and HCA, attempting to detect chemical differences and similarities that might cluster samples according to the wax source (propolis or comb), the provenance of the samples (which may be linked to the local flora and the genetics of the insects), or any other factor that might influence the chemical composition of the waxes.

\section{Results and Discussion}

PCA has been successfully used in propolis classifi- cation according to geography ${ }^{21}$ and plant source, and in the characterization of honeys ${ }^{22}$ from stingless bees. The data matrix used here correlated the composition of 50 wax samples with the relative amounts of 20 compounds (variables). The scores plotted along the first two principal components accounted for $50 \%$ of the total variation among all the variables taken into consideration. The first principal component (PC1) separated most samples collected in São Paulo from samples collected in the South, in some other Brazilian regions and Uruguay.

HCA provided a dendrogram of chemical affinities among the wax samples (Figure 1). Samples of Group I are chemically characterized by hydrocarbon fractions with high concentrations of alkanes C23, C25, C27 and monounsaturated alkenes $\mathrm{C} 33$ and $\mathrm{C} 35$. The main monoester alcohol moiety is $\mathrm{C} 24$ (tetracosanol) and the main acid moiety is C16:0 (palmitic acid). Therefore, the predominant monoester in these samples is expected to be a C40 compound (tetracosyl palmitate). In PCA analysis these constituents of Group I have negative values.

The comb and propolis waxes obtained from the same hives were collected in Ribeirão Preto (State of São Paulo). They are the following: $\operatorname{Pr} 1$ (14), $\operatorname{Pr} 2$ (14), $\operatorname{Pr} 3$ (14), Pr4 (14), Pr5 (14) (propolis waxes) and Co1 (14), Co2 (14), Co3 (14), Co4 (14) and Co5 (14) (comb waxes). Except for Pr2 (14), all samples belong to Group I. Among these samples, no consistent chemical differences were observed between propolis and comb waxes, as far as the distribution of hydrocarbons and ester constituents are concerned.

Group II is formed by 27 samples of propolis collected mainly in Southern Brazil (States of Paraná and Rio Grande do Sul), along with samples from other parts of the country, one sample from Uruguay (Pr24 (12)) and two samples of comb wax, namely Co2c(13) and Co1c(13) (Figure 1). The main difference between Groups I and II is that monoesters and $n$-alkanes of the latter possess, in average, longer carbon chains. In fact, the predominant esters of Group II are compounds $\mathrm{C} 48, \mathrm{C} 50$ and C52, formed by acid moieties $\mathrm{C} 18$ and C20 and alcohol moieties C30 and C32, as opposed to the $\mathrm{C} 40$ esters of Group I. The predominant $n$ alkanes have carbon chains C29-C33. The sample of comb wax Co1 (13) emerges from the HCA dendrogram together with the corresponding propolis wax [Pr1 (13), Figure 1], as being associated with mixed eucalyptus plus wild vegetation. These samples have PC1 scores close to zero. However, the sample of comb wax Co2 (13) is also part of Group II, but the corresponding propolis wax $(\operatorname{Pr} 2(13))$ is a component of Group I (Figure 1). Group II also comprises samples $\operatorname{Pr} 2$, Pr4-8 and Pr10-24, whose data were obtained from reference 12, and samples Pr2-6 (13) and $\operatorname{Pr} 2$ (14).

All samples of Group I (Figure 1) stemmed from the State of São Paulo (Southeast Brazil). This is one of the 


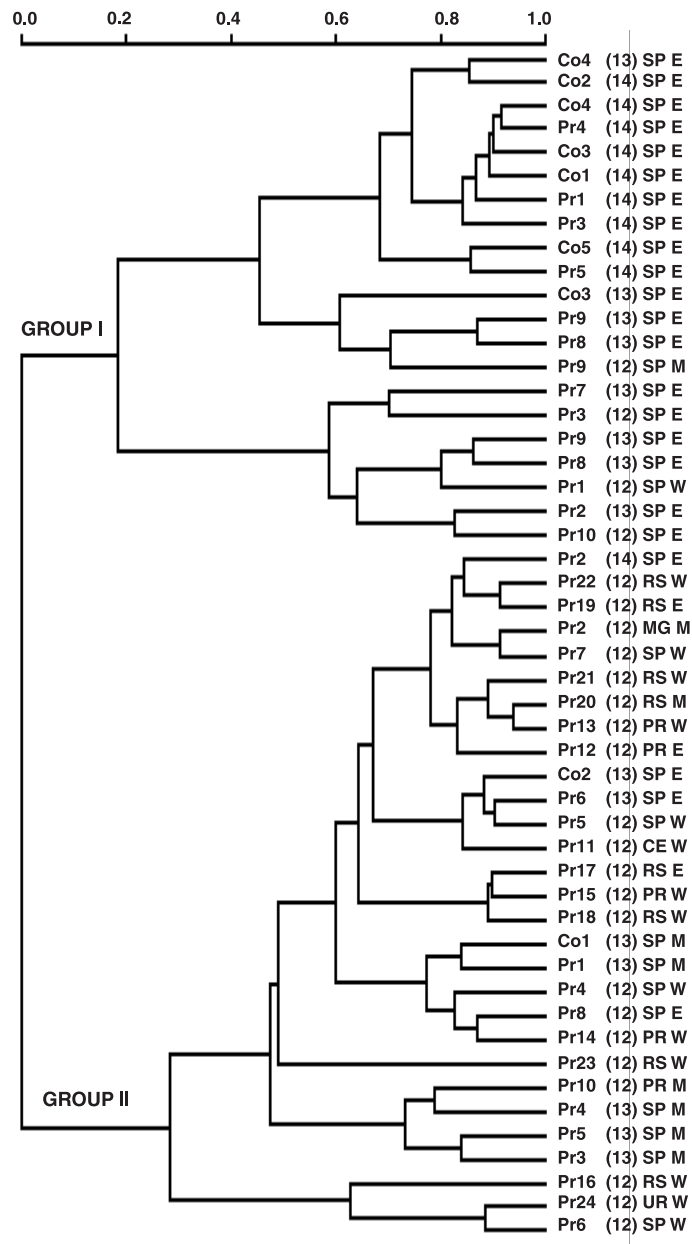

Figure 1. HCA clustering of samples of comb $(\mathrm{Co})$ and propolis (Pr) waxes, based on the distribution of hydrocarbons and ester moieties (linear long chain alcohols and carboxylic acids). Numbers in parentheses correspond to bibliographic references from which chemical data were obtained. CE, MG, PR, RS and SP correspond, respectively, to the Brazilian States Ceará (Northeast), Minas Gerais (Southeast), Paraná, Rio Grande do Sul (both in Southern Brazil) and São Paulo (Southeast); UR corresponds to Uruguay. E, M and W stand for, respectively, eucalyptus plantation, mixed and wild vegetation.

most salient features of the HCA analysis. Among the 29 samples of Group II, the majority came from the States of Paraná and Rio Grande do Sul (South). Flora and/or other factors related to geography might be factors influencing the similarity in chemical composition of samples of Group I, as suggested by PCA and HCA analysis. It could be argued that the associated flora might be a factor accounting for the split of the samples into two groups as depicted in Figure 1. Indeed, samples of Group I are associated predominantly with eucalyptus plantations, while samples of Group II are mostly linked to mixed or wild vegetation. However, it is unlikely that the vegetation surrounding the bee colonies has any influence on the distribution of typical constituents of beeswax, be it comb or propolis derived. The biosynthesis of typical wax constituents, such as hydrocarbons and esters, involve fatty acids as immediate precursors, both in plants and in insects, via the condensation-elongation ${ }^{23}$ mechanism. In turn, fatty acids are formed by the well known acetate-malonate pathway of primary metabolism. There is thus no involvement of secondary metabolites as biosynthetic precursors of typical beeswax constituents.

Therefore, the local flora could hardly influence the composition of beeswax. Comb wax has long been known to be a bee-secreted ${ }^{10}$ product. There are no strong reasons to refute the assumption that propolis wax ${ }^{12,13}$ may have a similar origin. Although in some cases samples of propolis and comb waxes collected from the same colonies (simultaneously or at different times) emerge in distinct clusters or even Groups of Figure 1 (such as Pr2 (14) and Co2 (14)), it is interesting to note that, among five combpropolis pairs collected simultaneously from the same colonies (corresponding to reference 14), three of them (Co1-Pr1, Co3-Pr3 and Co5-Pr5) are closely associated in Figure 1. Negri et al. ${ }^{13-14}$ also observed strong similarities between the distribution of hydrocarbons and esters of comb and propolis waxes and substantial differences in the comparison of both beeswaxes with plant waxes. In contrast, resins and volatile constituents of propolis are secondary metabolites, most of them ${ }^{24}$ derived from plants. Hence, in this case the botanical origin of the samples has a major influence on the composition of propolis resin.

A likely factor accounting for the split of the wax samples analyzed in the present work into distinct groups is the distribution of genetically distinct bee colonies which could account for the observed results. The coincidence that most samples from the State of São Paulo are combined, comprising Group I (Figure 1), and the fact that a site in the State of São Paulo was the center wherefrom the hybridization process irradiated is highly suggestive. Could it be that bees from this State possess a higher degree of africanization than bees from other parts of Brazil? An answer to this question is so far not available, but the fact that, in Brazil, the geographical location of the hives is strongly linked to the genetics of the bees has been well established, because the hybridization between European and African bees differ in degrees of genetic combination from one location to another (see Introduction). Studies using canonical trend surface, principal components and spatial auto-correlation analyses demonstrated that Africanized honey bees in southern and southeastern Brazil are more similar to European honey bees than those found in northern ${ }^{20}$ and northeastern regions. The clinal patterns of variation found for genetically independent characters support the hypothesis that larger honey bees in southern 
and southeastern Brazil originated by racial admixture in the initial phases of African honey bee ${ }^{16}$ colonization. Geographic variation patterns of africanized honey bee populations reflect a demic diffusion process in which European genes were gradually lost because of the higher fitness of the African gene pool in Neotropical ${ }^{16,20}$ environmental conditions.

\section{Experimental}

\section{Chemical data}

Chemical data for monoesters' alcohol and acid moieties, as well as aliphatic hydrocarbons, were drawn from references 12-14, where lists of samples of propolis and comb waxes, details of extraction and analysis methods and wax compositions are quoted. Reference 12 corresponds exclusively to data for propolis waxes; reference 13 , to propolis and comb waxes from different colonies. Reference 14 lists data for propolis and comb waxes from the same colonies. Samples of comb and propolis waxes stemmed from Uruguay (one sample), from the Brazilian States of Ceará (Northeast, one sample), Minas Gerais and São Paulo (Southeast Brazil), and Paraná and Rio Grande do Sul (South). Bee colonies were associated with either eucalyptus plantations, wild vegetation or mixed eucalyptus/wild vegetation.

\section{Multivariate analyses}

PCA and HCA techniques were applied to chemical data for propolis and comb waxes to estimate possible interactions between the measured parameters and evaluate possible similarities and differences among the two types of waxes and among sites of collection or associated flora. The chemical data treated by PCA and HCA correspond exclusively to the distribution of hydrocarbons (linear and branched alkanes and linear alkenes) and acid and alcohol moieties released by hydrolysis of long chain esters. Triterpenoids in propolis waxes reported in reference 14 were not considered for multivariate analyses. The data were scaled to unit variance and mean centered before modeling. The multivariate analyses were made using the program Pirouette Multivariate Data Analysis for IBM PC Systems, version 2.60 (Infometrix, Seattle).

\section{Acknowledgements}

The authors acknowledge financial support provided by FAPESP (Fundação de Amparo à Pesquisa do Estado de São Paulo, grants 95/9306-5 and 95/2790-9) and CNPq
(Conselho Nacional do Desenvolvimento Científico e Tecnológico).

\section{References}

1. Ghisalberti, E. L.; Bee World 1979, 60, 59.

2. Bankova, V.; Christov, R.; Kujumgiev, A.; Marcucci, M. C.; Popov, S.; Z. Naturforsch. 1995, 50C, 167.

3. Banskota, A. H.; Tezuka, Y.; Prasain, J.K.; Matsushige, K.; Saiki, I.; Kadota, S.; J. Nat.Prod. 1998, 61, 896.

4. Basnet, P.; Matsushige, K.; Hase, K.; Kadota, S.; Namba, T.; Biol. Pharm. Bull. 1996, 19, 1479.

5. Miyataka, H.; Nishiki, M.; Matsumoto, H.; Fujimoto, T.; Matsuka M.; Satoh, T.; Biol. Pharm. Bull. 1997, 20, 496.

6. Burdock, G. A.; Food Chem. Toxicol. 1998, 36, 347.

7. Woisky, R.G., Salatino, A.; J. Apic. Res. 1998, 37, 99.

8. Seifert, M.; Haslinger, E.; Liebigs Ann. Chem. 1989, 11, 1123.

9. Seifert, M.; Haslinger, E.; Liebigs Ann. Chem. 1991, $2,93$.

10. Hamilton, R. J. In Waxes: Chemistry, Molecular Biology and Functions; Hamilton, R. J., ed.; The Oily Press: Dundee, Australia, 1995, p.257.

11. Szerletics-Turi, M.; Acta Aliment. Hung. 1999, 28, 85.

12. Negri, G.; Marcucci, M. C.; Salatino, A.; Salatino, M. L. F.; Apidologie 1998, 29, 305.

13. Negri, G.; Marcucci, M. C.; Salatino, A.; Salatino, M. L. F.; J. Braz. Chem. Soc. 2000, 11, 453.

14. Negri, G.; Marcucci, M. C.; Salatino, A.; Salatino, M. L. F.; J. Apic. Res. 2000, 39, 86.

15. Pereira, A. S.; Pinto, A. C.; Cardoso, J.N.; Aquino Neto, F. R.; Ramos, M.F.S.; Dellamora-Ortiz G. M.; Santos, E. P.; J. High Resol. Chromatogr. 1998, 21, 396.

16. Lobo, J. A.; Del Lama, M. A.; Mestriner, M. A.; Evolution. 1989, 43, 794.

17. Lobo, J. A.; Krieger, H.; Heredity. 1992, 68, 441.

18. Diniz, J. A. F.; Malaspina, O.; Evolution. 1995, 49, 1172.

19. Diniz, J. A. F.; Hepburn, H.R.; Radloff, S.; Fuchs, S.; Apidologie 2000, 31, 191.

20. Diniz, J. A. F.; Malaspina, O.; Braz. J. Genetics 1996, 19, 217.

21. Marcucci, M. C.; Ferreres, F.; Custódio, A. R.; Ferreira, M. M. C.; Bankova, V. S.; Garcia-Viguera, C.; Bretz, W. A.; Z. Naturforsch. 2000, 55C, 76.

22. Vit, P.; Oddo, L. P.; Marano, M. L.; Mejias, E. S.; Apidologie 1998, 29, 377

23. Wettstein-Knowles, P. In Waxes: Chemistry, Molecular Biology and Functions; Hamilton, R. J., ed.; The Oily Press: Dundee, Australia, 1995, p. 91.

24. Marcucci, M.C.; Apidologie 1995, 26, 83.

Received: January 11, 2002

Published on the web: February 21, 2003

FAPESP helped in meeting the publication costs of this article. 